\title{
The Practicality of Learning Module Based on Jigsaw-Cooperative Learning Model in Media Education Course
}

\author{
Zonny Amanda Putra, Arwizet, Bulkia Rahim, Rahmat Azis Nabawi \\ Mechanical Engineering Department, Engineering Faculty \\ Universitas Negeri Padang \\ Padang, Indonesia \\ zonnyap@gmail.com
}

\begin{abstract}
Educational factors that are less appropriate in the delivery of materials and the selection of instructional media causes lesson objectives are perfectly acceptable by students. The educational factors here are defined as the facilities needed in the learning process such as learning media used by lecturers. Based on the problems and goals to be achieved, this type of research is a quasi-experimental research (quasi experiment). Quasi experimental research is a research method used to look for certain influences against others in controlled conditions. In general, the approaches taken in this research were investigative and survey. Results test practicality module Theory of Media Education model of cooperative type of jigsaw according to the lecturer was $97,50 \%$, so it can be concluded the module fell into the category of "Very Practical". Students responded positively to the use of Jigsaw Education Model in the implementation of learning with average response of $83.65 \%$ belonged to very practical category. Of the thirteen statement items in the questionnaire, all statements were answered very practically by the students. This further strengthened the average of all the items by $83.65 \%$. There was an increase in learning outcome on pretest to post-test of $31.82 \%$.
\end{abstract}

Keywords_-Jigsaw Type Cooperative, Module, Practicality

\section{INTRODUCTION}

The essence of the teaching and learning process is the process of communication in which the delivery of information from sources of information through certain media to the recipient of information. There are several reasons regarding the use of the media, including: the lesson will attract more students, the lesson material will be more easily understood by the students, the teaching method will be more varied, and the students will do more learning activities [1].

Educational factors that are less appropriate in the delivery of materials and the selection of instructional media causes lesson objectives are perfectly acceptable by students. Educational factors here are defined as the facilities needed in the learning process such as learning media used by lecturers. It is important that the selection of instructional media is the material needed by lecturers in interaction with the students. Student learning process is influenced by learning media both on campus and at home [2].

The lack of teaching materials or learning resources is one part of the cause of the minimum understanding of students in the learning subjects Media. Therefore, adding references and reproduce teaching materials in Education
Media lesson may support the ability of students in understanding the lesson. The results of the Semester of JulyDecember 2016, which has two sections of the Education Media course, the students' competence is also not maximized as shown in Table 1.

TABLE I. Semester VAlue of Education Media Semester JULY-DECEMBER 2016

\begin{tabular}{|c|c|c|c|c|}
\hline \multirow{2}{*}{ No } & $\begin{array}{c}\text { Value Interval } \\
\text { Number }\end{array}$ & $\begin{array}{c}\text { Value } \\
\text { Interval } \\
\text { Alphabet }\end{array}$ & $\begin{array}{c}\text { Frequ- } \\
\text { ency (f) }\end{array}$ & $\begin{array}{c}\text { Percen- } \\
\text { tage (\%) }\end{array}$ \\
\hline 1 & $0-39$ & $\mathrm{E}$ & 5 & 8,47 \\
\hline 2 & $40-49$ & $\mathrm{D}$ & 0 & 0,00 \\
\hline 3 & $50-54$ & $\mathrm{C}-$ & 1 & 1,69 \\
\hline 4 & $55-69$ & $\mathrm{C}$ & 5 & 8,47 \\
\hline 5 & $60-64$ & $\mathrm{C}+$ & 5 & 8,47 \\
\hline 6 & $65-69$ & $\mathrm{~B}-$ & 13 & 22,03 \\
\hline 7 & $70-74$ & $\mathrm{~B}$ & 13 & 22,03 \\
\hline 8 & $75-79$ & $\mathrm{~B}+$ & 11 & 18,64 \\
\hline 9 & $80-84$ & $\mathrm{~A}-$ & 6 & 10,17 \\
\hline 10 & $85-100$ & $\mathrm{~A}$ & 0 & 0,00 \\
\hline Amount & & 59 & 100,00 \\
\hline Small Value 64, Value under C+ & & 16 & 27,12 \\
\hline Great Value 65, Value above B- & & 73 & 72,88 \\
\hline
\end{tabular}

Based on Table 1, out of 59 students, only 43 students $(72.88 \%)$ score 65 or above (B- and up). While, from under 65 students, there are 16 students $(27.12 \%)$, which means almost one-third of the total number of students in the first semester of class of 2014 is below 65 and there are values below 40 or E score of $8.47 \%$. This seems to be caused by the lesson of the course which gives students the opportunity to be able to understand the concept of methodology and apply it in the learning activities.

To overcome these symptoms and problems, researchers tried to use learning methods that make students more active. In order to increase student activeness, Jigsaw cooperative learning method was used. Researchers chose cooperative learning method Jigsaw model because in the learning process, students can develop themselves in groups, mutual opinion, and not only fixated in one group as in other methods and in this Jigsaw model all students in groups are required to be active to prevent the domination of one or two students only. Another factors that makes researchers chose Jigsaw learning model are: (1) this learning model can encourage students to express their ideas verbally and compare with their friends' ideas. This is especially meaningful when in the troubleshooting process, (2) this 
learning model can train students to express opinions, (3) this learning model can improve their communication skills.

Lie stated that, Jigsaw is one type or model of flexible cooperative learning [3]. Much research has been done in relation to the cooperative learning model on the basis of Jigsaw. The research has consistently shown that students involved in this Jigsaw Model Cooperative learning achieve better performance, have better and more positive attitudes toward learning, in addition to mutual respect for differences and opinions of others.

According to Abdul Majid, "the module is a book written with the aim that learners can learn independently without teacher guidance, so the module contains at least the basic components of teaching materials that have been mentioned previously. This makes students required to learn independently to increase learning motivation and learning outcomes "[4].

Module is a tool or means of learning in which in the form of materials, methods and evaluations are made systematically and structured as an effort to achieve the objectives of the expected competencies. Module is designed specifically and clearly based on the speed of understanding of each student, thus encouraging students to learn accordingly with their ability. Module is printed materials designed to be studied independently by the learning participants [5]. Proposed module can be formulated as: a complete unit that stands alone and consists of a series of learning activities arranged to help students achieve a number of objectives that are formulated specifically and clearly [6]. Cepi Riyana stated that in order to produce module capable of improving the motivation and effectiveness of their use, module development should consider the following characteristics [7].

\section{A. Self Instructuional}

It is an important characteristic of the module since it enables one to learn independently and not be dependent on others. To fulfill the character of self instruction, the module must: (1) make clear goals and can describe the achievement of competency standards and basic competencies, (2) load learning materials packaged in small / specific activities units, making it easier to learn thoroughly, (3) have examples and illustrations that support the clarity of exposure of learning materials, (4) have practice questions, tasks and the like that make it possible to measure mastery, (5) be contextual, the material presented related to the atmosphere, task or context of activities and student environment, (6) use simple and communicative language, (8) have a summary of learning materials, (9) have an assessment instrument that enables learners to conduct their own assessment (selfassessment), (10) have feedback on learners, so learners know the level of mastery of the material, (11) have information about referrals/enrichment/ references that support learning materials.

\section{B. Self Contained}

Modules are said to be self-contained when all required learning materials are contained in the module. The purpose of this concept is to provide opportunities for students to learn the learning materials completely because the learning materials packed into a unified whole. If there should be a division or separation of material from one standard of competence, it should be done carefully and should pay attention to the breadth of competency standards that must be mastered by the students.

\section{Stand Alone}

Stand alone is a module characteristic that is not dependent on teaching materials or other media or should not be used in conjunction with other media. So students do not need to use other teaching materials to learn the module. If the students still use and rely on instructional materials other than the modules used, they are not included as stand-alone modules.

\section{Adaptive}

Modules should have a high adaptation to the development of science and technology. It is said to be adaptive if the module can adjust to the development of science and technology, as well as flexible.

\section{E. Friendly}

Modules also should meet user friendly rules or familiar with the user. Every instruction and exposure of information that appears to be helpful and friendly with the user, including ease of use in responding and accessing as you wish. Modules are prepared using active sentences with simple, easy-to-understand language and use commonly used terms

According to E. Mulyasa the main purpose of the module is to improve the efficiency and effectiveness of learning, including time, funds, facilities, and energy to achieve goals optimally [8]. The purpose of teaching modules for students according to S. Nasution, among others: (1) opening opportunities for learners to learn according to their own speed. (2) providing an opportunity for learners to learn in their own way, depending on the background knowledge and learning habits of each learner. (3) giving the choice of a large number of topics in a particular subject or field of study to learners who do not share the same interests or motivations to achieve the same goals, (4) providing opportunities for learners to recognize their advantages and disadvantages and improve the weaknesses of each learner through repetitions or variations in how to learn [5].

According to Asmar Yulastri et al, learning using modules can improve learning outcomes of learners. A valid, practical and effective module allows learners to be interested in reading as it is attractive [9]. Modules have some advantages as learning media such as mastery, increase students' motivation to self study, overcome the limitations of time, space, as well as the senses of both students and lecturers and understand the ability of each student [10]. Educational media is a medium whose use is integrated with the purpose and content of teaching that is usually intended to optimize the achievement of a teaching and learning activities.

Learning media contains material about communication theory and learning, media concepts and principles, types and kinds of media, learning media characteristics, organizational systems and media selection, advantages and disadvantages, two-dimensional non-projection learning media, printed media, three dimensional media / model , projection media, photography, computer-based media, Audio Visual media, and interactive multimedia. Designing, creating and displaying learning media. 
The framework of this research, shows that the influence of the use of learning methods using modules in learning is expected to increase student activity and learning outcomes. With the application of learning method using module, it is expected that students get motivated, active and the learning result will increase. Broadly speaking the relationship of variables with regard to this experimental research can be formulated in the form of a chart used as a guide in the preparation of this research instrument as seen in Figure 1.

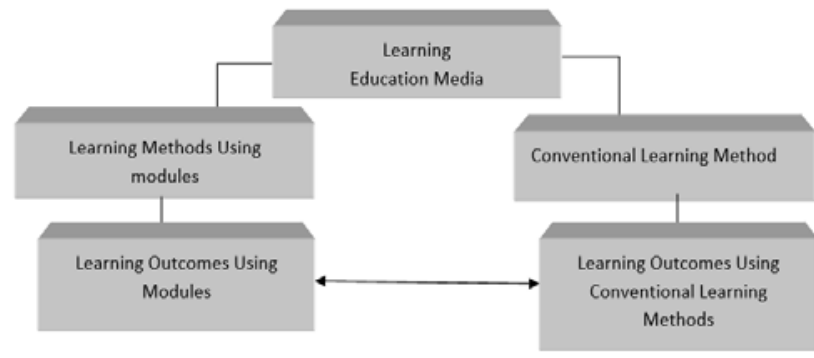

Fig. 1. Conceptual Research

\section{METHOD}

Based on the problems and goals to be achieved, then this type of research is a quasi-experimental research (quasi experiment). Quasi experimental research is a research method used to look for certain effects on others in controlled conditions. Quasi experimental research aims to examine the cause and effect relationship by providing one or more treatment conditions to one or more experimental groups and comparing the results to one or more control groups that are not receiving treatment. In general, the approaches taken in this research were investigation and survey [11].

In this research there are 2 groups which are experiment group and control group determined by cluster random sampling technique. Both groups are assumed to be the same and differ only in the application of the learning method. The experimental group was the treated group, while the control group was taught using conventional learning method. Meanwhile, the control group in this study was as a comparison for the experimental group.

\section{RESUlt AND Discussion}

Practicality test data of Education Model Module Jigsaw model of co-operative model on the subject of Media Education was taken from questionnaires that have been distributed to lecturers and students.

\section{1) Lecturer Practicality}

Practicality relates to the ease of use of the developed Jigsaw model of Education Model module. Practicality of the Education Model module of the jigsaw cooperative model was obtained from practitioners' responses to the practicality of the Jigsaw model of the Education Model module. Practitioners for lecturers' responsiveness of lecturers who taught the subjects of Media Education on Jigsaw cooperative model.

\section{2) Student Practicality}

The practicality of Education Model module Jigsaw cooperative model was also obtained from the responses of the students respondents about the practicality of the use of media-based module of Education model jigsaw cooperative.

\section{A. Lecturers Response.}

Practicality relates to the ease of use of the developed Jigsaw model of Education Model module education. Practicality data was obtained through a questionnaire filled by a practitioner (Lecturer of Media Education). From the questionnaire, it can be seen that the practicality of using the Education Model module jigsaw type cooperative model. The results of assessment on the practicality of Education Model module jigsaw model co-operative model can be seen in table 2. below:

TABLE II. LECTURERS' ReSPONSE DATA ABOUT THE PRACTICALITY of Module Media EduCATION Model JigSAW CoOperative Model

\begin{tabular}{|l|l|l|l|}
\hline No. & \multicolumn{1}{|c|}{ Indicator } & value & Category \\
\hline 1 & $\begin{array}{l}\text { This learning module is easy to use in } \\
\text { accordance with the wishes of users }\end{array}$ & 5 & very practical \\
\hline 2 & $\begin{array}{l}\text { The use of the Education Media } \\
\text { learning module can generate student } \\
\text { interest in learning }\end{array}$ & 5 & very practical \\
\hline 3 & $\begin{array}{l}\text { Learning by using this Media Education } \\
\text { learning module makes students more } \\
\text { quickly to understand the material }\end{array}$ & 5 & very practical \\
\hline 4 & $\begin{array}{l}\text { The use of this Education Media } \\
\text { Learning module can save the time and } \\
\text { energy of Lecturers in the presentation } \\
\text { of learning materials }\end{array}$ & 5 & very practical \\
\hline 5 & $\begin{array}{l}\text { The learning module used can be } \\
\text { interpreted by the lecturer }\end{array}$ & 5 & very practical \\
\hline 6 & $\begin{array}{l}\text { The use of this Education Media } \\
\text { module can make learning more } \\
\text { interesting }\end{array}$ & 4 & very practical \\
\hline 7 & $\begin{array}{l}\text { Learning Media Education module is } \\
\text { designed according to the material }\end{array}$ & 5 & very practical \\
\hline 8 & $\begin{array}{l}\text { Media Education learning module can } \\
\text { be used as a means of self-learning }\end{array}$ & 5 & very practical \\
\hline Amount & $\mathbf{3 9}$ & very practical \\
\hline Final Score
\end{tabular}

Table 2 shows the result of practicality test module of cooperative type of jigsaw type according to the lecturer was $97,50 \%$, so that it can be concluded that module goes in the category of "Very Practical".

\section{B. Students Response}

The practicality of the jigsaw type cooperative module also required students' response. This data was obtained through a questionnaire given to 32 students after learning using a jigsaw type cooperative module. To capture the students' response to the effectiveness of the use of modules, thirteen statements were employed. The thirteen statements are: (1) Using the learning model module of jigsaw type cooperative model let me know the purpose of learning that I do. (2) I can learn jigsaw cooperative type education media with module. (3) Using a jigsaw type cooperative module can help learn independently. (4) It is easy to use this jigsaw type cooperative learning module (5) Explanation / drawing / table in the module can make it easier to understand the concept of learning activities. (6) It is easy to read the text and sentences that exist in the learning module Jigsaw Cooperative Education Media type. (7) It is easy to 
understand the language used in this jigsaw type cooperative learning model. (8) Jigsaw type cooperative modules are designed according to the material. (9) Jigsaw type cooperative modules developed can improve my reasoning to understand learning materials (10) Jigsaw type cooperative learning modules help me to easily understand the materials of Education Media. (11) Jigsaw type cooperative learning modules motivate me to learn Education Media. (12) Jigsaw type cooperative learning model attract my interest to learn Education Media. (13) Jigsaw type cooperative learning modules makes me more active in learning.

TABLE III. STUdents' Response DAta ABOUT THE PRACTICALITIES of Module Media Education Model Jigsaw Cooperative Model

\begin{tabular}{|c|c|c|c|c|c|c|c|}
\hline \multirow{2}{*}{$\begin{array}{c}\text { State } \\
\text { ment } \\
\text { numb } \\
\text { er }\end{array}$} & \multicolumn{5}{|c|}{ choice of answers } & \multirow{2}{*}{$\begin{array}{c}\text { Percent } \\
\text { age of } \\
\text { assesme } \\
\text { nt (\%) }\end{array}$} & \multirow[b]{2}{*}{ category } \\
\hline & $\begin{array}{l}V A \\
\text { (5) }\end{array}$ & $\begin{array}{l}A \\
\text { (4) }\end{array}$ & $\begin{array}{l}L A \\
\text { (3) }\end{array}$ & $\begin{array}{l}D A \\
(2)\end{array}$ & $\begin{array}{c}V D \\
A \\
(1) \\
\end{array}$ & & \\
\hline 1 & 12 & 16 & 4 & & & 85 & $\begin{array}{l}\text { very } \\
\text { practical }\end{array}$ \\
\hline 2 & 11 & 16 & 5 & & & 83,75 & $\begin{array}{l}\text { very } \\
\text { practical }\end{array}$ \\
\hline 3 & 19 & 6 & 6 & 1 & & 86,88 & $\begin{array}{l}\text { very } \\
\text { practical }\end{array}$ \\
\hline 4 & 10 & 13 & 9 & & & 80,6 & $\begin{array}{l}\text { very } \\
\text { practical }\end{array}$ \\
\hline 5 & 16 & 10 & 6 & & & 86,25 & $\begin{array}{l}\text { very } \\
\text { practical }\end{array}$ \\
\hline 6 & 9 & 17 & 6 & & & 81,88 & $\begin{array}{l}\text { very } \\
\text { practical }\end{array}$ \\
\hline 7 & 12 & 12 & 8 & & & 82,5 & $\begin{array}{l}\text { very } \\
\text { practical }\end{array}$ \\
\hline 8 & 10 & 18 & 4 & & & 83,75 & $\begin{array}{l}\text { very } \\
\text { practical }\end{array}$ \\
\hline 9 & 14 & 14 & 4 & & & 86,25 & $\begin{array}{l}\text { very } \\
\text { practical }\end{array}$ \\
\hline 10 & 12 & 12 & 8 & & & 82,5 & $\begin{array}{l}\text { very } \\
\text { practical }\end{array}$ \\
\hline 11 & 11 & 13 & 8 & & & 81,88 & $\begin{array}{l}\text { very } \\
\text { practical }\end{array}$ \\
\hline 12 & 10 & 16 & 6 & & & 82,5 & $\begin{array}{l}\text { very } \\
\text { practical }\end{array}$ \\
\hline 13 & 11 & 16 & 5 & & & 83,75 & $\begin{array}{l}\text { very } \\
\text { practical }\end{array}$ \\
\hline \multicolumn{6}{|c|}{ Average } & 83,65 & $\begin{array}{l}\text { very } \\
\text { practical }\end{array}$ \\
\hline
\end{tabular}

Based on the questionnaire results above, it appears that the students responded positively to the use of Jigsaw Type Co-operative module in the implementation of learning with the average response of $83.65 \%$ in very practical category. Of the thirteen statement items in the questionnaire, all statements were answered very practically by the students. This further strengthened the average of all the items by $83.65 \%$. This was in accordance with student learning outcomes before and after using the module that can be seen in table 4. Here is the average of student learning outcomes before and after using the module.

This study involves Jigsaw cooperative education model module for Education Media course. The development of this module is based on the preliminary observation of the learning process of Media Education aiming to find out the problems, obstacles, and any phenomena encountered in the field in connection with learning Media Education. In addition, needs analysis, such as curriculum analysis and student analysis, was also conducted. This jigsaw cooperative module has passed the test of validity, practicality and effectiveness.

TABLE IV. STUDENTS' RESPONSE DATA ABOUT THE PRACTICALITIES of Module Media EduCATION MODEL JigSAW COOPERATIVE MODEL

\begin{tabular}{|l|c|c|l|}
\hline \multicolumn{2}{|c|}{ average experimental class learning outcomes } & \multirow{2}{*}{ enhancement } \\
\cline { 1 - 3 } Number of Students & pretest & $\begin{array}{c}\text { Post-test With } \\
\text { Module }\end{array}$ & \\
\hline 32 & 49,22 & $\mathbf{8 1 , 0 4}$ & 31,82 \\
\hline
\end{tabular}

Giving the module printed to the students seemed to contribute to their achievement in following the lecture. The logic is that by giving the printed module, the usual time taken to record the material can be reduced and the concentration of students to work on learning can be improved. This was apparently due to module components such as basic competencies and indicators that they can explicitly read from this module. In accordance with the concept of learning as stated in the concept of micro learning, the understanding and concentration of students can be improved if they know, from the beginning, the learning objectives and activity steps that can be done during the learning. Practical testing was done by asking opinion to lecturers and students through practicality questionnaire sheets. From practice test, it was known that the Education Model module of jigsaw cooperative model was in very practical category to be used as learning module.

\section{CONCLUSION}

Practicality of modules in learning can be seen from the implementation of the use of Education Model module jigsaw cooperative model as a whole. This was seen from the response of lecturers with the average percentage of $97.50 \%$ and student response results obtained an average percentage of $83.65 \%$. This indicates that the Jigsaw type of Education Education model modules developed were in the "very practical" category. Testing the use of this module in learning showed that the module has been prepared very practical as a means of teaching Media Education courses. There was an increase in learning outcome on pretest to posttest of $31.82 \%$.

\section{REFERENCES}

[1] Nana Sudjana \& Ahmad Rivai. 2007. Teknologi Pengajaran. Bandung: Sinar Baru Algensindo.

[2] Benny Pribadi. 2009. Model Desain Sistem Pembelajaran. Jakarta : PT. Dian. Rakyat.

[3] Lie Anita, 2005. Coopertive Learning (mempraktikkan cooperative learning di ruang-ruang kelas). Jakarta: Grasindo.

[4] Abdul Majid. 2006. Perencanaan Pembelajaran.Bandung:PT.Remaja Rosdakarya.

[5] Direktorat Tenaga Kependidikan. 2008. Penulisan Modul. (online). Diakses pada tanggal 5 Februari 2017.

[6] S. Nasution. 2005. Bebagai Pendekatan Dalam Proses Belajar Dan Mengajar. Jakarta: PT. BumiAksara.

[7] Rudi Susilana, Cepi Riyana. 2008. Media Pembelajaran. Bandung: CV Wacana.

[8] E.Mulyasa. 2005. Kurikulum Berbasis Kompetensi. Konsep, Karakteristik, Implementasi Dan Inovasi. Bandung: PT. Remaja Rosdakarya.

[9] Asmar Yulastri et al. (2017). Developing an Entrepreneurship Module by Using Product-Based Learning Approach in Vocational Education. 
International Journal Of Environmental \& Science Education 2017, VOL. 12, NO. 5, 1097-1109.

[10] Vinokurova, N.F., Krivdina, N.V.M.Y., Badin, M.M. \& Efimova, .E. (2016). Master's Program Module "Environmental Issues - Decision Making Experience" as Precondition for Implementation of Education for Sustainable Development for Professional Training of Teachers. International Journal of Environmental and Science Education, $11(15), 8628-8636$

[11] Suharsimi Arikunto. 2006. Prosedur Penelitian Suatu Pendekatan Praktik. Jakarta: PT. Rineka Cipta. 